\title{
Synthesis of Pullulan by Acetone-dried Cells and Cell-free Enzyme from Pullularia pullulans, and the Participation of Lipid Intermediate ${ }^{\dagger}$
}

\author{
Ryo Taguchi, * Yoshiyuki Sakano, Yo Kikuchi, Munekatsu Sakuma \\ and Tsuneo KOBAYASHI** \\ Department of Agricultural Chemistry, Tokyo Noko University, \\ Fuchu, Tokyo, 183
}

Received December 18, 1972

\begin{abstract}
It was demonstrated that the polysaccharide, pullulan, was synthesized from sucrose by acetone-dried cells of Pullularia pullulans or from UDPG by cell-free enzyme preparations prepared from the organism. The pullulan formed was estimated by precipitation with ethanol, and determining maltotriose produced after treating the precipitate with Aerobacter isoamylase (pullulanase). Acetone cells $(5 \mathrm{~g})$ shaken with $200 \mathrm{ml}$ of $10 \%$ sucrose produced over $250 \mathrm{mg}$ of pullulan per $100 \mathrm{ml}$ after $90 \mathrm{hr}$ at $30^{\circ} \mathrm{C}$ and $\mathrm{pH} 6.0$. Cell-free enzyme produced pullulan from UDPG in the presence of ATP. ATP was essential for the biosynthesis, and ADPG could not replace for UDPG.

In addition, it was observed that a lipid containing glucose residue was formed during. the reaction. The nature of this glucolipid was examined, and possible participation of a lipid intermediate was assumed in the pullulan biosynthesis.
\end{abstract}

In the previous papers ${ }^{1,2)}$ the authors have reported on the structure of polysaccharides produced by Pullularia pullulans. We have now studied on the biosynthetic mechanism of pullulan, the extracellular homoglucan produced by the organism. Ueda et $a l^{3 \prime}$ has reported the formation of polysaccharide by washed cells of $P$. pullulans, and suggested possible participation of transglucosidase action in the process. ${ }^{4)}$

In the present paper, experimental results will be described on the formation of pullulan from sucrose or UDPG by acetone-dried cells of $P$. pullulans and cell-free enzyme preparation prepared therefrom. Some evidences showing possible participation of lipid intermediate in the process will be also described.

$\uparrow$ Polysaccharide Production by Pullularia pullulans. Part III. See Reference 2) for the Part II.

* Present address: Department of Microbial Chemistry, Faculty of Pharmaceutical Sciences, Nagoya City University, Mizuho-ku, Nagoya.

** To whom inquiries should be addressed.

\section{MATERIALS AND METHODS}

Materials. UDPG and ATP were generous gifts from Yamasa Shoyu Co., Ltd. ADPG was purchased from Boehringer Mannheim GmbH. Aerobacter isoamylase (pullulanase, EC 3.2.1.9 Amylopectin 6-glucanohydrolase) preparations free from $a$-amylase and glucoamylase was prepared from Aerobacter aerogenes as in previous paper.1

Organism. Pullularia pullulans S-1 supplied by Professor S. Ueda, Kyushu University, was used throughout this study.

Preparation of washed cells and acetone-dried cells. The organism was cultured for $30 \mathrm{hr}$ as described in the previous paper. ${ }^{1 /}$ Cells harvested by centrifugation were washed thrice with physiological saline, and stored in the saline overnight. The cells collected by centrifugation was used as washed cells.

For preparing acetone-dried cells, fresh cells were washed twice with water, suspended in a small amount of water, and poured into 20 volumes of cold acetone at $0^{\circ} \mathrm{C}$. Precipitated cells were filtered, washed with cold acetone and then by ether, and dried in vacuo. About $15 \sim 20 \mathrm{~g}$ of acetone-dried cells was obtained from 2 liters culture broth. Bacterial growth was not observed with acetone cells incubated in nutrient media. 
Preparation of cell-free enzyme. Cells harvested after $36 \sim 40 \mathrm{hr}$ of culture were washed with water, frozen, ground with 2 times their weight of alumina, extracted with 5 volumes of $0.05 \mathrm{M}$ phosphate buffer (pH 7.0), and centrifuged at $10,000 \times g$ for $20 \mathrm{~min}$. The precipitate salted-out from the supernatant with 0.8 saturation of ammonium sulfate was dissolved in a small amount of water, and insoluble material removed by centrifugation at $1500 \times g$ for $10 \mathrm{~min}$. The solution obtained was used as the enzyme. Enzyme preparations were analyzed for protein content, and diluted so as to give the protein content $20 \mathrm{mg} / \mathrm{ml}$.

\section{Polysaccharide synthesis}

l) With washed cells. Washed cells (wet weight $0.5 \mathrm{~g}$ ) was shaken with $100 \mathrm{ml}$ of $10 \%$ sugar solution containing $0.1 \mathrm{M}$ phosphate buffer $(\mathrm{pH} 6.0$ or 7.0 ) at $27^{\circ} \mathrm{C}$. Aliquots of reaction mixture were taken at proper time intervals, and centrifuged to remove cells. Polysaccharide formed was prepipitated with $50 \%$ ethanol, and redissolved in water. Total carbohydrate was determined on an aliquot of the solution, and another aliquot was subjected to the action of excess Aerobacter isoamylase at $40^{\circ}$ for $2 \mathrm{hr}$. Reducing sugar produced after isoamylase action was determined, and analyzed with paper chromatography.

2) With acetone-dried cells. Five g of acetonedried cells was shaken with $200 \mathrm{ml}$ of $10 \%$ sucrose solution containing $0.1 \mathrm{M}$ phosphate buffer $(\mathrm{pH} 6.0)$ at $30^{\circ} \mathrm{C}$, and the reaction was followed by the methods described above. The reaction was carried out with sterilized vessels under hood to prevent bacterial contamination.

3) With cell-free enzyme. Reaction mixture contained $40 \mu$ moles of UDPG, $40 \mu$ moles of ATP, $50 \mu \mathrm{l}$ of $0.1 \mathrm{M}$ Tris- $\mathrm{HCl}$ (or phosphate) buffer $(\mathrm{pH} \mathrm{7.0)}$ ), $50 \mu 1$ of $0.1 \mathrm{M} \mathrm{MgCl}_{2}$, and $50 \mu 1$ of enzyme in total volume $250 \mu 1$. The mixture was incubated at $30^{\circ} \mathrm{C}$ for $90 \mathrm{~min}$, and boiled to stop the reaction. An aliquot of the reaction mixture was treated with isoamylase at $40^{\circ} \mathrm{C}$ for $2 \mathrm{hr}$, and then heated in $0.05 \mathrm{~N}$ $\mathrm{HCl}$ at $100^{\circ} \mathrm{C}$ for $10 \mathrm{~min}$ to decompose UDPG remaining in the solution. The solution was neutralized, and analyzed for reducing sugar. Another aliquot was taken as blank from the boiled reaction mixture, treated in $0.05 \mathrm{~N} \mathrm{HCl}$ at $100^{\circ} \mathrm{C}$ for $10 \mathrm{~min}$, neutralized, and its reducing sugar content was determined. The value of reducing sugar in the blank was subtracted from values of isoamylase-treated sample, and reducing sugar was calculated as maltotriose.

Experiments on lipid intermediate. Acetone-dried cells were shaken with reaction mixtures containing radioactive sucrose, and lipid fraction was extracted from aliquots of the mixture taken at intervals, and washed by the method of Folch et al. ${ }^{5}$ Radioactivity in the lipid fraction obtained was measured in a Packard Tri-Carb liquid scintilation counter, and the nature of the fraction was examined with thin-layer chromatography (TLC) and paper chromatography, hydrolysis by acid or alkali, and treatment with phenol. Details of this line of experiments were given under RESULTS.

Analytical methods. Total carbohydrate was estimated by phenol-sulfuric acid method, $\left.{ }^{6}\right)$ and reducing sugar was determined by Nelson-Somogyi method. ${ }^{7,8}$ Paper chromatography of sugars was run on Toyo No. 51 filter paper with descending method using $n$-butanol-pyridine-water $(6: 4: 3)$ solvent. Location of sugars on chromatograms was detected with silver nitrate-acetone reagent.

Determination of protein was made by measuring optical density at $280 \mathrm{~nm}$, or by the method of Lowry et al. ${ }^{9}$

TCL of lipid fraction was carried out on Silicagel $\mathrm{G}$ (Merck) plates with solvents, $n$-butanol-acetic acidwater $(6: 2: 2)$ (solvent A), or chloroform-methanolwater $(65: 25: 1)$ (solvent B). Paper chromatography of lipid fraction was done on Toyo No. 51A filter paper with a solvent, isobutyric acid-1 $\mathrm{N} \mathrm{NH}_{4} \mathrm{OH}(5: 3)$.

\section{RESULTS}

\section{Formation of pullulan by washed cells}

In Table I were shown the amounts of polysaccharide produced from several sugars by washed cells of $P$ pullulans after incubation for $20 \mathrm{hr}$ at $27^{\circ} \mathrm{C}$. An example of time course

\section{Table I. Yteld of Polysaccharide Produced By Washed Cells of $\boldsymbol{P}$, pullulans}

Five $\mathrm{g}$ of wet cells was incubated with $100 \mathrm{ml}$ of $10 \%$ substrate solution for $20 \mathrm{hr}$ at $27^{\circ} \mathrm{C}$.

\begin{tabular}{lcc}
\hline \multirow{2}{*}{ Substrate } & \multicolumn{2}{c}{ Yield $(\mathrm{g} / 100 \mathrm{ml})$} \\
\cline { 2 - 3 } & $\mathrm{pH} 6.0$ & $\mathrm{pH} 7.0$ \\
\hline Glucose & 0.32 & - \\
Sucrose & 0.77 & 0.70 \\
Maltose & 0.97 & 0.90 \\
\hline
\end{tabular}

of polysaccharide production from sucrose was shown in Fig. 1. Optimum conditions for polysaccharide production were at $\mathrm{pH}$ $6.0 \sim 7.0$, and around $30^{\circ} \mathrm{C}$. Action of isoamylase on the polysaccharide followed by paper chromatography revealed that the product after isoamylase action was almost solely 


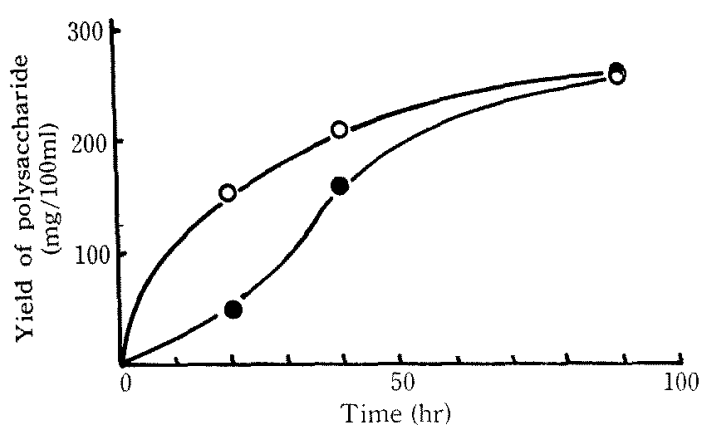

FIG. 1. Polysaccharide Formation by Washed Cells and Acetone Cells of $P$. pullulans.

$0-\mathrm{O}$, Washed cells, $0.5 \mathrm{~g}$ cells in $100 \mathrm{ml}$ of $10 \%$ sucrose, pH $6.0,27^{\circ} \mathrm{C}$; - Acetone cells, $5 \mathrm{~g}$ cells in $200 \mathrm{ml}$ of $10 \%$ sucrose, $\mathrm{pH} 6.0,30 \mathrm{C}$.

maltotriose, indicating that the majority of the polysaccharide formed was pullulan.

On the other hand, culture filtrate of the organism had no activity of polysaccharide production.

Formation of pullulan from sucrose by acetonedried cells

Experiments with acetone-dried cells were carried out in a similar way as above, and similar results were obtained, an example being shown in Fig. 1. But results were rather variable with the batch of acetone-dried cells, and several oligosaccharides were formed from sucrose or maltose as substrate. In these experiments, bacterial growth was not observed until the reaction period of $90 \mathrm{hr}$.

Table II. Pullulan Synthesis from Nucleotide Sugar by Cell-free Enzyme from $P$. pullulans

The yield was expressed in $\%$ of moles of glucose residue incorporated into pullulan from moles of glucose moiety in nucleotide sugar.

Reaction conditions: $\mathrm{pH} 7.0,30^{\circ} \mathrm{C}$ for $90 \mathrm{~min}$. See text for experimental details.

\begin{tabular}{cc}
\hline $\begin{array}{c}\text { Substrate } \\
\text { and additives }\end{array}$ & $\begin{array}{c}\text { Yield of pullulan } \\
\text { (pullulan/nucleotide } \\
\text { sugar) }\end{array}$ \\
\hline UDPG + ATP (phosphate buffer) & $54 \%$ \\
UDPG + ATP (Tris-HCl buffer) & 38 \\
- ATP & 0 \\
ADPG + ATP & 0 \\
- ATP & 0 \\
\hline
\end{tabular}

Synthesis of pullulan from UDPG by cell-free enzyme

Cell-free enzyme was not able to form pullulan from sucrose. But considerable amounts of pullulan were produced when cell-free enzyme was incubated with UDPG in the presence of ATP. As shown in Table II, pullulan was formed only from reaction mixture containing UDPG and ATP, and not from UDPG or ADPG alone, nor from ADPG plus ATP. The reaction mixture from UDPG plus ATP after incubation was spotted on a filter paper, and irrigated with developing solvent. A strip of filter paper including the origin was cut out, and the polysaccharide fraction remaining at the origin was extracted with boiling water. The extract was treated with excess isoamylase, and the digest was again chromatographed. Only maltotriose was detected on chromatogram, showing the synthesis of pullulan from UDPG in the presence of ATP.

Evidences for the presence of lipid intermediate

Experiment 1. A reaction mixture containing $0.4 \mathrm{~g}$ of sucrose- ${ }^{14} \mathrm{C}\left(4.7 \times 10^{4} \mathrm{cpm}\right)$, $4 \mathrm{ml}$ of $0.1 \mathrm{M}$ phosphate buffer $(\mathrm{pH} 7.0)$, and $0.1 \mathrm{~g}$ of acetone-dried cells was shaken at $30^{\circ} \mathrm{C}$. At times $0.5 \mathrm{ml}$ aliquots were removed from the reaction mixture, boiled to inactivate enzymes, extracted with $5 \mathrm{ml}$ of chloroformmethanol (2:1) mixture, and the organic layer was washed with 0.2 volume of water. The extracts were concentrated, spotted on small pieces of filter paper, and their radioactivities were measured. It was observed that the radioactivity was incorporated into lipid fraction, and reached the maximum after 90 min, when about $3.4 \%$ of radioactivity was incorporated. The results were shown in Fig. 2, curve A, in which values were expressed in per cent to the maximum value.

Experiment 2. A reaction mixture containing $5 \mathrm{~g}$ of sucrose $-{ }^{14} \mathrm{C}\left(3.8 \times 10^{5} \mathrm{cpm}\right)$, $50 \mathrm{ml}$ of $0.1 \mathrm{M}$ phosphate buffer $(\mathrm{pH} \mathrm{7.0)}$ and $1.3 \mathrm{~g}$ of acetone-dried cells was shaken at 


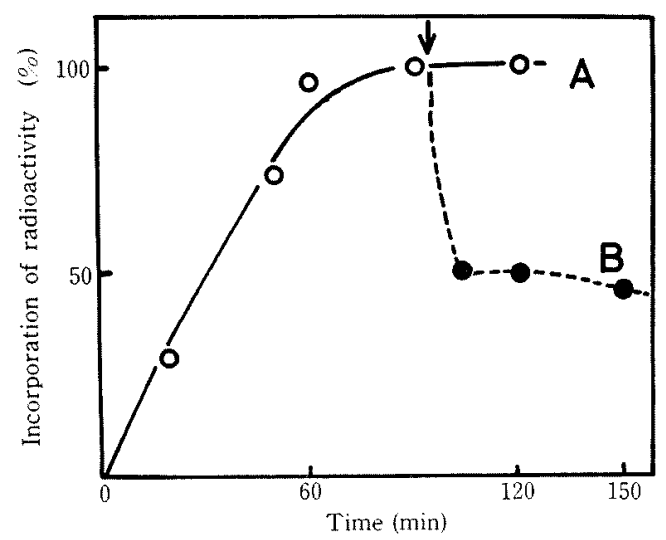

FIG. 2. Incorporation of Radioactivity into Lipid Fraction from Sucrose-14 $\mathrm{C}$ by Acetone-dried Cells of P. pullulans.

The arrow indicates the time of addition of nonlabeled sucrose.

$30^{\circ} \mathrm{C}$. After 30,60 and $90 \mathrm{~min}, 5 \mathrm{ml}$ aliquots were withdrawn from the mixture, immediately centrifuged, and the supernatants were extracted with 10 volumes of chloroformmethanol (2:1) mixture. Immediately after the withdrawal of $90 \mathrm{~min}$-sample, $30 \mathrm{ml}$ of $10 \%$ non-labeled sucrose solution was added to the reaction mixture. Ten $\mathrm{ml}$ each of samples was further withdrawn at 105, 120 and $150 \mathrm{~min}$, and extracted as above. Each extract was concentrated, dried on a small piece of filter paper, and its radioactivity was measured. The results were shown in Fig. 2, curve B. As seen from the Fig., a rapid and substantial decrease in radioactivity of lipid fraction was observed after the addition of non-labeled sucrose.

\section{Nature of lipid intermediate}

Properties and structure of lipid intermediate obtained from experiments with sucrose $-{ }^{14} \mathrm{C}$ were examined by TLC, paper chromatography, hydrolysis with acid and alkali, and warm phenol treatment.

1) TLC and paper chromatography. Distribution of radioactivity in TLC was shown in Fig. 3. The radioactivity showed single peaks with both solvents $\mathrm{A}$ and $\mathrm{B}$, the $R f$ being 0.46 and 0.17 , respectively. In paper

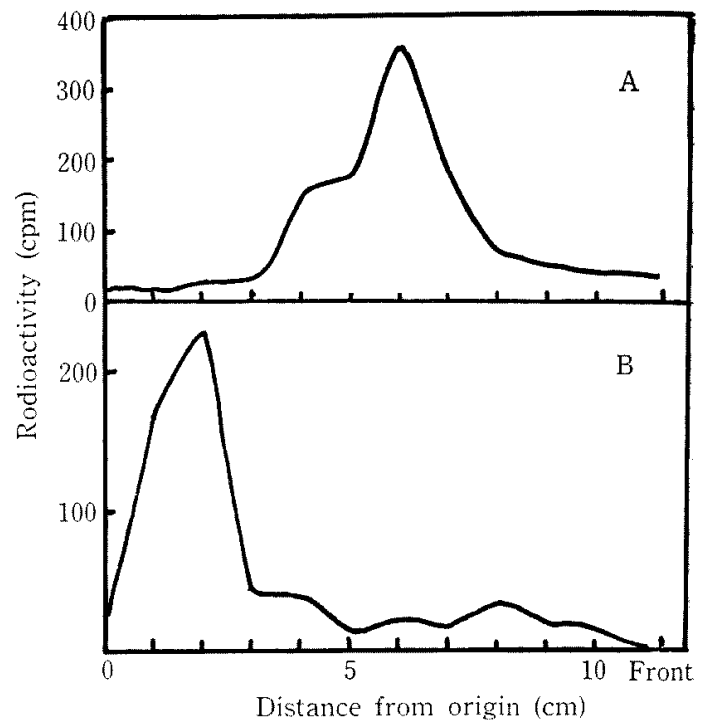

FIG. 3. Radiochromatogram of Lipid Fraction in Thin-layer Chromatography.

A : $n$-butanol-acetic acid-water $(6: 2: 2)$

B : chloroform-methanol-water $(65: 25: 1)$

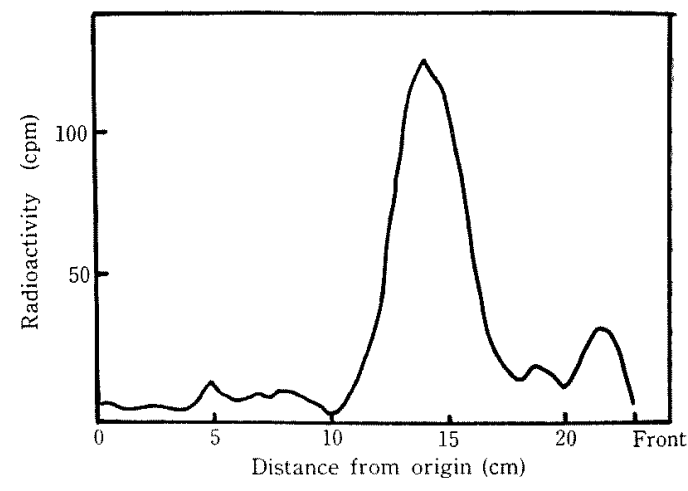

FIG. 4. Radiochromatogram of Lipid Fraction in Paper Chromatography.

Solvent : isobutyric acid-1 N NH${ }_{4} \mathrm{OH}(5: 3)$

chromatography, the lipid fraction was chromatographed, $1-\mathrm{cm}$ strips of chromatogram were cut out, and radioactivity of each strip was measured. The radioactive component had a single peak at $R f 0.55$ as shown in Fig. 4 .

2) Acid hydrolysis. A portion of lipid fraction containing $200 \mathrm{cpm}$ was dried under a stream of nitrogen. To this sample $0.05 \mathrm{ml}$ of methanol and $0.5 \mathrm{ml}$ of $0.01 \mathrm{~N} \mathrm{H}_{2} \mathrm{SO}_{4}$ were added, and the mixture was heated at $100^{\circ} \mathrm{C}$ 
Table III. Distribution of Radioactrvity between Aqueous and Organic Phases after Acid and Alkaline Hydrolysis, and Warm Phenol TREATMENT OF THE LIPID Fraction

\begin{tabular}{lcc}
\hline \multicolumn{1}{c}{ Treatments } & $\begin{array}{c}\text { Aqueous } \\
\text { phase }\end{array}$ & $\begin{array}{c}\text { Organic } \\
\text { phase }\end{array}$ \\
\hline Acid hydrolysis & $85 \%$ & $15 \%$ \\
Alkaline hydrolysis & 83 & 17 \\
Warm phenol treatment & 100 & 0 \\
\hline
\end{tabular}

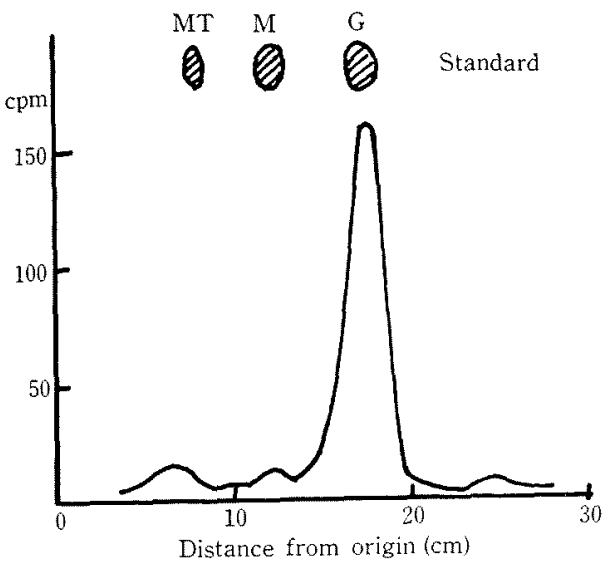

FIG. 5. Radioactivity on Paper Chromatogram of Aqueous Layer from the Acid Hydrolyzate of the Lipid Fraction.

MT : Maltotriose, M : Maltose, G : Glucose.

for $20 \mathrm{~min}$. After cooling, $3 \mathrm{ml}$ of water, and $2 \mathrm{ml}$ of chloroform were added to the sample, and after vigorous shaking upper and lower phases were separated by a syringe. Radioactivity was estimated on both fractions. As shown in Table III, $85 \%$ of radioactivity was present in aqueous phase.

A portion of the aqueous phase after acid hydrolysis was chromatographed on paper, and glucose, maltose and maltotriose were run in parallel as standards. Distribution of radioactivity was estimated, and standards were detected. Results indicated that radioactive substance behaved exactly as glucose (Fig. 5).

3) Alkaline hydrolysis. A portion of lipid fraction dried under nitrogen stream was taken in $0.8 \mathrm{ml}$ of water-saturated $n$-butanol containing $0.25 \mathrm{~N} \mathrm{NaOH}$. The mixture was heated at $48^{\circ} \mathrm{C}$ for $2 \mathrm{hr}$, a trace of methanol being added to maintain a single phase. The alkaline butanolic solution was washed twice with water, and distribution of radioactivity in both organic and aqueous layers was estimated. As shown in Table III, the majority of radioactivity was in the aqueous phase.

4) Warm phenol treatment. To a portion of lipid fraction dissolved in $100 \mu 1$ methanol was added $900 \mu \mathrm{l}$ of water and $1 \mathrm{ml}$ of aqueous $90 \%$ phenol $(\mathrm{v} / \mathrm{v})$. After heating at $60^{\circ} \mathrm{C}$ for $5 \mathrm{~min}$, the mixture was cooled and extracted twice with $4 \mathrm{ml}$ portions of ether. The radioactivity of both organic and aqueous layers were estimated. All of the radioactivity was in aqueous phase, as shown in Table III.

\section{DISCUSSION}

While the structure of pullulan, the extracellular polysaccharide produced by $P u l-$ lularia pullulans, was studied by several workers, ${ }^{1,10 \sim 12)}$ very little is known at present about the biosynthetic mechanism of the polysaccharide except that Ueda et al. ${ }^{3)}$ has observed the formation of polysaccharide by washed cells from sucrose. In the present paper, we were able to demonstrate that pullulan is synthesized by acetone-dried cells and cell-free enzyme preparations through transglycosylation from UDPG, and to suggest possible participation of a lipid intermediate in the process.

There was theoretically another mechanism of polysaccharide synthesis, i.e., by the transglycosylation from performed saccharides as in the case of dextran synthesis from sucrose by dextransucrase. But this possibility was unlikely, since pullulan was formed only by cell suspension and cell-free enzyme from cell homogenate, and not by culture filtrate incubated with sucrose. Ueda and Kono ${ }^{4)}$ has suggested possible participation of transglycosylation from oligosaccharides in the process. The formation of several oligosaccharides, which are probably the products of transglycosylation from sucrose, was also observed in the present study with acetone- 
dried cells and cell-free enzyme, in spite of the inability of cell-free enzyme to synthesize pullulan from sucrose. The result led to the consideration that the products of transglycosylation from sucrose are not directly related to the pullulan biosynthesis.

It is generally approved that nucleotide sugars are concerned in the biosynthesis of many polysaccharides. Present result that pullulan was formed from UDPG now adds a new example to this group of polysaccharides synthesized through nucleotide sugars. It is to be noted that ATP is required in pullulan synthesis from UDPG. Though the role of ATP is not clear at present, it would be assumed that ATP is concerned in the formation of lipid intermediate, which will be discussed below.

The occurrence of lipid intermediate in polysaccharide biosynthesis was first shown by Anderson et al. ${ }^{13}$ in the synthesis of cell-wall peptidoglycan by Staphylococcus, and several examples were accumulated on the biosynthesis of cell wall polysaccharides. In the present study, we have at first noted a change in TLC pattern of lipid fraction from acetone cells during pullulan synthesis. On further examination we are able to demonstrate that radioactivity was incorporated from sucrose $-{ }^{14} \mathrm{C}$ and into lipid fraction by acetone-dried cells under the same conditions for pullulan synthesis. The radioactive lipid thus formed was shown to be of very rapid turnover, as indicated by a rapid decrease in radioactivity of the lipid fraction after addition of nonlabeled sucrose, as shown in Fig. 2.

The nature and structure of the lipid intermediate was further studied, and following results were obtained: (1) it showed single peak in TLC as well as in paper chromatography, (2) it contained glucose moiety, and (3) it contained pyrophosphate linkage. The last-cited statement was made from results of mild alkaline hydrolysis and warm phenol treatment. These treatments were known to split pyrophosphate linkages in sugar-containing phospholipid. ${ }^{14,15\}}$ When the label was in the sugar moiety, the radioactivity became water-soluble after these treatments. Results in Table III indicated that it is exactly the case. Thus the structure of the lipid intermediate assumed here was considered to be of the type, Lipid- $(\overline{\mathrm{P}}-\mathrm{P}-\mathrm{Glucose}$, as presented by Anderson et al. ${ }^{16}$

The evidence for the lipid intermediate in pullulan synthesis would be not yet complete at present. Further characterization of the intermediate, and the formation of pullulan from this intermediate must be demonstrated for confirmation. But the fact that the pullulan synthesis and the formation of a lipid fraction containing glucose with very high turnover proceeded in parallel under the same conditions strongly suggests the occurrence of the lipid intermediate in the process.

Acknowledgements. We are grateful to Professor Seinosuke Ueda, Kyushu University, for supplying the strain of the organism, and to Yamasa Shoyu Co., Ltd., Choshi, Chiba Prefecture, for ample supply of UDPG and ATP. We are also grateful to Messrs. Takamu Kawasaki, Fusao Kimizuka, and Hideki Kono for technical assistance. This study was supported in part by the Scientific Research Grant from the Ministry of Education.

\section{REFERENCES}

1) R. Taguchi, Y. Kikuchi, Y. Sakano and T. Kobayashi, Agr. Biol. Chem., 37, 1583 (1973).

2) Y. Kikuchi, R. Taguchi, Y. Sakano and T. Kobayashi, ibid., 37, 1751 (1973).

3) S. Ueda, K. Komatsu, K. Fujita and Z. Nakashima, Appl. Microbiol., 11, 211 (1963); S. Ueda, Kogyo Kagaku Zasshi, 67, 757 (1964).

4) S. Ueda and H. Kono, Appl. Microbiol., 13, 882 (1965).

5) J. Folch, M. Lees and G. H. Shoan Stanley, J. Biol. Chem., 226, 497 (1957).

6) J. H. Hodge and B. T. Hofreiter, "Methods in Carbohydrate Chemistry," Vol. I, ed. by R. L. Whistler and M. L. Wolfrom, Academic Press Inc., New York, 1962, p. 388.

7) N. Nelson, J. Biol. Chem., 153, 375 (1944).

8) M. Somogyi, ibid., 195, 19 (1952).

9) O. H. Lowry, N. J. Rosebrough, A. L. Farr and R. T. Randall, ibid., 193, 265 (1951).

10) H. Bender und K. Wallenfels, Biochem. Z., 334, 79 (1961).

11) H. O. Bouveng, $\mathrm{H}$. Kiessling, B. Lindberg and J. McKay, Acta Chem. Scand., 16, 615 (1962). 
2) B. J. Catley and W. J. Whelan, Arch. Biochem. Biophys., 141, 138 (1971).

3) J. S. Anderson, M. Matsuhashi, M. A. Haskin and J. L. Strominger, Proc. Natl. Acad. Sci., U. S., 53, 881 (1965).

4) A. Wright, M. Dankert, P. Fennessey and P. W. Robbins, Proc. Natl. Acad. Sci., U.S., 57, 1798
(1967)

15) J. L. Kent and M. J. Osborn, Biochemistry, 7, 4396 (1968).

16) J.S. Anderson, M. Matsuhashi, M. A. Haskin and J. L. Strominger, J. Biol. Chem., 242, 3180 (1967). 